\title{
Similative and equative demonstratives in \\ Kambaata
}

Yvonne Treis ${ }^{1}$

\section{INTRODUCTION}

The study of comparison of similarity and equality and the study of deixis intersect in the domain of similative and equative demonstratives. Similative demonstratives are here understood as demonstratives that relate to the multidimensional notions of manner (1a) and quality (1b) and establish a similarity relation, while equative demonstratives relate to the one-dimensional notions of degree (1c) and quantity (1d) and establish an equality relation between a referent and a target of demonstration. ${ }^{2}$ Manner and quality demonstratives are hence subsumed under the label "similative demonstratives", degree and quantity demonstratives under the label "equative demonstratives" (Table 1).

\begin{tabular}{|l|l|l|}
\hline & Ontological type & Typical syntactic function \\
\hline \multirow{2}{*}{ Similative } & Manner & adverbial \\
\cline { 2 - 3 } & Quality & adnominal \\
\hline \multirow{2}{*}{ Equative } & Degree & adverbial \\
\cline { 2 - 3 } & Quantity & adnominal \\
\hline
\end{tabular}

Table 1. Similative and equative demonstratives.

\footnotetext{
${ }^{1}$ LLACAN, CNRS-INALCO-Université Sorbonne Paris Cité, email: yvonne.treis@cnrs.fr 2 Abbreviations: A_adjective, AAM proprietive, AAN agentive, ABL ablative, ACC accusative, ADD additive, APP apprehensive, BDV benedictive, CAUS causative, COND conditional, CONF confirmation, COP copula, CRD coordinative, DAT dative, DEF definite, DEM demonstrative, DS different subject, EQ equative, F feminine, G manner nominalizer, GEN genitive, HON honorific/impersonal, ICO imperfective converb, ICP instrumental-comitative-perlative, IDEO ideophone, IMP imperative, INTJ interjection, IPV imperfective, L linker, IRR irrealis, LOC locative, M masculine, MID middle, MIT mitigation, MULT multiplicative, N "emphasis", NCO negative converb, NEG negation, NIPV non-imperfective, NMZ nominalizer, NOM nominative, NREL negative relative, O object, OBL oblique, P plural, $\mathrm{P}_{-}$pronoun, PASS passive, PCO perfective converb, PFV perfective, PL plurative, PN proper noun, POSS possessive, PRED predicative, PRES presentative, PRF perfect, PROG progressive, PST past, PURP purposive, Q question, REAS reason, REL relative, S singular, SG singulative, SIM similative, SS same subject.
}

\footnotetext{
*Pre-publication version*

Treis, Yvonne forthcoming (2019). Similative and equative demonstratives in Kambaata. Faits de Langues. (Special issue Comparaisons d'égalité et de similitude et expression de la simulation, ed. by Claudine Chamoreau \& Yvonne Treis.)
} 
Kambaata, a Highland East Cushitic language of Ethiopia, uses the same demonstratives for the identification of degree and quantity (1c-d) and formally related demonstratives for the identification of manner and quality (1a-b). Quality and quantity demonstratives are typically used adnominally, manner and degree demonstratives as adverbs to verbs, adjectives and ideophones.

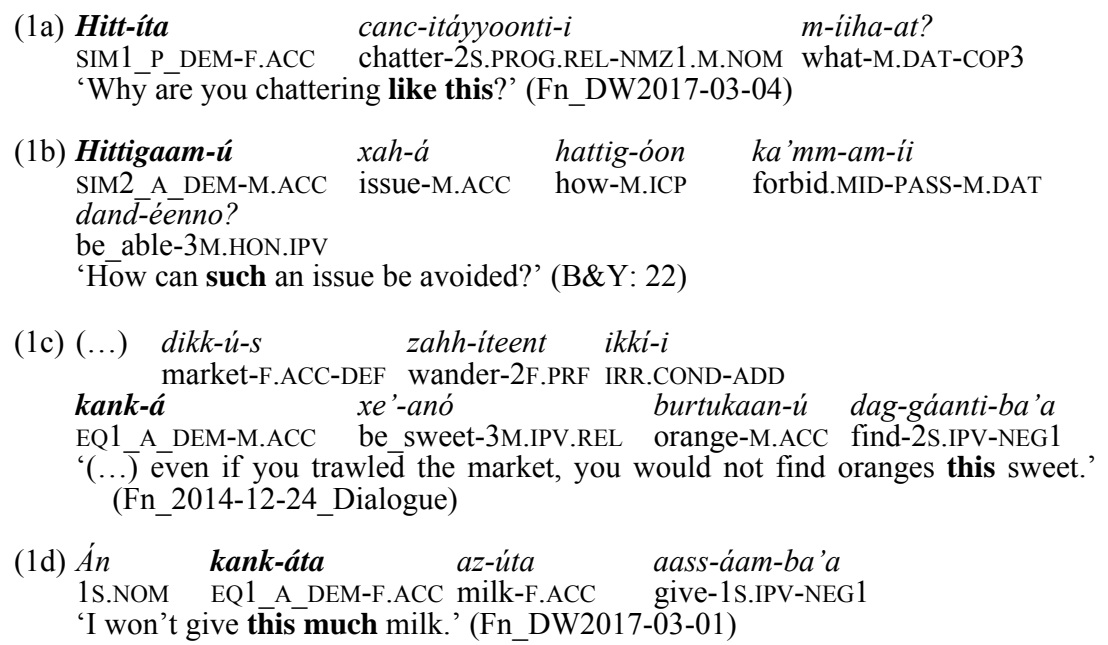

Whereas earlier typological works on demonstratives, e.g. Andersen \& Keenan (1985), Diessel (1999) and Dixon (2003), have paid little attention to similative and equative demonstratives, our knowledge has been significantly expanded in recent years, firstly, by case studies of individual languages; see, for instance, the works by Umbach on the multifunctional German so (e.g. Umbach \& Ebert 2009, Umbach \& Gust 2014 and the literature cited there), van der Auwera \& Sahoo (2015) on similative demonstratives in English, Dutch and Odia (Indo-Aryan), and van der Auwera \& Coussé (2016) on similative demonstratives in English and Swedish, to name but a few. ${ }^{3}$ Secondly, cross-linguistic studies have contributed to a better understanding of the domain; see Guérin's (2015) work on manner demonstrative verbs and, most importantly, the typology of manner, quality and degree demonstratives by König $(2012,2015,2017)$ and König \& Umbach (2018). The latter contribution shows that some languages use the same demonstrative for manner, quality and degree (e.g. German so and Turkish böyle), whereas others oppose a manner/quality to a degree demonstrative (e.g. Spanish asi vs. tan) or use a different one for each semantic category (archaic English thus vs. such vs. so). While many languages neutralise the spatial oppositions (e.g. between proximal, medial and distal) in the domain of manner, quality and degree

${ }^{3}$ Note that van der Auwera and colleagues do not speak of "similative demonstratives" but simply of "similatives". 
demonstratives, languages such as Japanese retain these oppositions: koo 'like this (speaker proximal)', soo 'like this (hearer proximal)', aa 'like that (distal)'). Finally, König \& Umbach (2018) distinguish between languages with and without morphologically simplex (non-compositional) demonstratives. Although König \& Umbach take a decidedly cross-linguistic perspective, their language sample is fairly small, as in-depth studies of equative and similative demonstratives in nonIndo-European languages are still lacking.

This paper aims to make a contribution to the study of little known equative and similative demonstratives in languages outside of Europe and takes Kambaata as an example. The paper significantly expands the preliminary analyses of these demonstratives, as presented in Treis (2008). After the typological profile of the language has been sketched in $\$ 2$, an introduction to similative and equative constructions is given in $\S \S 3-4$ and an overview of the demonstrative system is provided in $\$ 5$. These sections sketch the necessary background for the analysis of similative demonstrative pronouns for the identification of manner ( $\$ 6.1)$, similative demonstrative adjectives for the identification of quality ( $\$ 6.2)$, and equative demonstrative adjectives for the identification of degree and quantity (§6.3). $\$ 7$ discusses the relationship between demonstratives and interrogatives before the paper is summarised in $\S 8$.

As the introductory examples in (1) show, I propose to integrate a fourth semantic domain in the study of similative and equative demonstrative, namely quantity demonstratives. To the best of my knowledge, degree and quantity demonstratives are not treated apart in the (limited number of) typological studies on similative and equative demonstratives. ${ }^{4}$ However, given that there are languages that distinguish between (mostly adverbial) manner and (mostly adnominal) quality demonstratives, some of them even using formally entirely unrelated terms (see e.g. König \& Umbach 2018), one can expect to also find languages that distinguish between degree and quantity demonstratives, i.e. languages where adverbial degree and adnominal quantity demonstratives manifest no syncretism. Quantity demonstratives definitely merit closer scrutiny in future descriptions of demonstrative systems.

\section{TYPOLOGICAL PROFILE OF KAMBAATA}

Kambaata is a language of the agglutinating-fusional type and strictly suffixing. Its constituent order is consistently head-final. The following open word classes can be defined on morphosyntactic grounds: nouns, adjectives, verbs, ideophones and interjections. Kambaata is a nominative-accusative language. The nominative is the subject case (see láah-u 'prince' in (2)); the accusative marks direct objects and certain adverbial constituents, and also serves as the citation form of nouns. Nouns are marked for gender (feminine vs. masculine) and case; nouns (and pronouns) distinguish 9 case forms, as illustrated by masculine and feminine example nouns in Table 2.

${ }^{4}$ However Haspelmath \& Buchholz (1998: 298-301) dedicate a separate section to quantitative equatives in their typological study of equative constructions. 


\begin{tabular}{|l|l|l|}
\hline & $\mathrm{M}$ & $\mathrm{F}$ \\
\hline Accusative (ACC) & dum-á & gat- $i$ - $a$ \\
\hline Nominative (NOM) & dúm- $u$ & gát- $i$ - $t$ \\
\hline Genitive (GEN) & dum- $i$ & gat-é \\
\hline Dative (DAT) & dum- $i$ i $(-h a)$ & gat-ée(-ha) \\
\hline Ablative (ABL) & dum-íichch & gat-éechch \\
\hline Instrumental-comitative-perlative (ICP) & dum-íin & gat-éen \\
\hline Locative (LOC) & dum-áan & gat-éen \\
\hline Oblique (OBL) & dúm- $a$ & gát-e \\
\hline Predicative (PRED) & dúm- $a$ & gát- $i$ \\
\hline
\end{tabular}

Table 2. Case paradigm of the nouns dum-á (M) 'back room' and gat-i-ta (F) 'back yard'5

For the discussion of similative and equative demonstrative adjectives (in $\$ \$ 6.1$ 3 ), it is also important to highlight some grammatical features of adjectives. In their prototypical use as modifiers in a noun phrase, they show case and gender agreement with the head noun. In this function, three case forms are distinguished: nominative, accusative and oblique (Table 3 ). The oblique case signals agreement with a non-nominative, non-accusative head noun, see ább-aa in (2).

(2) Hitta j-áata qakkíchch-u láah-u A DEM2.F.ACC time-F.ACC small-M.NOM prince-M.NOM áb $b-a a \quad$ kichchechch-iin wiimm-o big-M.OBL sadness-M.ICP fill-3M.PFV 'Then (lit. at that time) the little prince was overcome with great sadness.' (QL 2018)

\begin{tabular}{|l|l|l|}
\hline & $\mathrm{M}$ & $\mathrm{F}$ \\
\hline Accusative & $a b b-a ́$ & $a b b-a ́ t a$ \\
\hline Nominative & $a ́ b b-u$ & $a ́ b b-a t$ \\
\hline Oblique & $a ́ b b-a(a)$ & $a ́ b b-a(t a)$ \\
\hline
\end{tabular}

Table 3. Case paradigm of the modifying adjective $a b b-a(t a)$ 'big'6

All adjectives can become heads of noun phrases too. As such, they have the same case-marking potential as nouns and are marked for the nine nominal cases (Table 2): accusative, nominative, genitive, dative, ablative, instrumental-comitativeperlative, locative, oblique and predicative. The predicative is the case of adjectival predicates. As NP heads, adjectives adopt the gender of the omitted head noun; in (3), the derived adjective gorr-áam- $u$ 'hungry' is masculine because the missing head noun is mánchu $(\mathrm{M})$ 'man, person'?

\footnotetext{
${ }^{5}$ Kambaata nouns fall into 21 declensions; table 2 presents a noun of masculine declension M1 and of feminine declension F2a.

${ }^{6}$ Kambaata adjectives fall into five declensions; table 3 presents an adjective of declension A1.

${ }_{7}$ See also the adjective maq-aam- $u$ 'strong, big' used as an NP head in (48).
} 
(3) Gorr-áam-u ang-áta aa'll-únna it-áno hunger-AAM-M.NOM hand-F.ACC wash.MID-3M.NCO eat-3M.IPV 'A hungry (person) eats without washing (his/her) hands.' (A\&A 2017)

Adjectives are also used as adverbial modifiers of verbs. In this function, they are invariably masculine and marked for an adverbial case (often the accusative).

The Kambaata data in this paper is presented in the official orthography (Treis 2008: 73-80), to which I added accents to indicate phonemic stress. ${ }^{8}$ The description is based on data from narratives, conversational data, elicited data as well as examples from locally published written sources (see appendix 'Sources').

\section{SIMILARITY}

In similative constructions the standard of comparison is marked by an enclitic morpheme $=g$ (glossed $\mathrm{G})$, the diachronic source of which is a noun meaning 'manner' (for details see Treis 2018). The enclitic element is marked for case, either the ACC/OBL case if the standard phrase is an adverbial (4-5), ${ }^{9}$ or the PRED case if the standard phrase is the predicate of the clause (6). The standard marker $=g$ encliticises to a genitive-marked noun (4) or noun phrase (5).

(4) Xabar $-i=\boldsymbol{g}-a \quad$ binn $=y-i$

ashes-M.GEN $=\mathrm{G}-\mathrm{M} . \mathrm{ACC} / \mathrm{OBL}$ disperse. $\mathrm{IDEO}=\mathrm{say}-2 \mathrm{~S} . \mathrm{IMP}$

'May you be dispersed like ashes!' (Curse) (AN2016-02-19_002)

(5) Hitt-íta gugán-at woqqar-too-sí

SIM1_P_DEM-F.ACC thunder-F.NOM strike-3F.PFV-3M.O.REL

man-ch-í $=\mathbf{g}-a \quad$ mexx-é

person-SG-M.GEN=G-M.ACC/OBL single-MULT jump.IDEO=say-1S.PCO

xóqq $=y-i \quad$ uurr-éemm

rise.IDEO=say-1S.PCO stand up-1S.PFV

'I jumped up, thunderstruck (lit. like a man whom thunder had struck).' (QL 2018)

(6) Aní-i kii-haa $=\boldsymbol{g}$-anka

1S.NOM-ADD 2S.GEN-M.COP2 $=$ G-M.PRED $<\mathrm{N}>$

'Me, too, I am/do like you.' (Fn_2004)

In attributive similative constructions, the standard of comparison is dependent on the relativised locative copula yoo- 'be located, exist' (COP1). It is ungrammatical to drop the relative verb yóo '(who) are' in (7); unlike in English (students like Awwano), a standard phrase cannot directly modify a comparee noun in Kambaata.

${ }^{8}$ The following graphemes are not in accordance with IPA conventions: $<\mathrm{ph}>/ \mathrm{p} /,<\mathrm{x}>/ \mathrm{t} /$, $<\mathrm{q}>/ \mathrm{k} ' /,<\mathrm{j}>/ \mathrm{d} 3 /,<\mathrm{c}>/ \mathrm{t}{ }^{\prime} /,<\mathrm{ch}>/ \mathrm{t} \mathrm{f} /,<\mathrm{sh}>/ \mathrm{J} /,<\mathrm{y}>/ \mathrm{j} /$ and $\left\langle{ }^{\prime}>/ \mathrm{P} /\right.$. Geminate consonants and long vowels are marked by doubling, e.g. $<$ shsh $>/$ f:/ and $<$ ee $>/$ e:/.

${ }^{9}$ In the case paradigm of $=g$, accusative and oblique are not distinguished. 


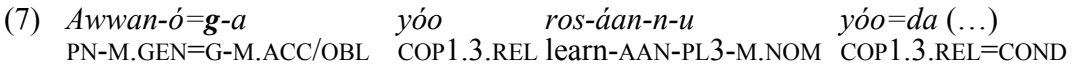
'(...) if there are students like Awwano (lit. students who are like Awwano).' (K89: 2.8)

The morpheme $=g$ is not only a standard marker in similative and equative comparison (for the latter see next section) but also a fully productive manner nominaliser with full case-marking potential. It combines with any type of modifier phrase and thus generates nominalised phrases that are translatable as 'manner of [(pro)noun]', '[adjective] manner' or 'manner that [relative clause]'. The resulting manner phrases can assume any syntactic function and any semantic role in the clause; in (8) the manner nominalisation is the subject of the clause and thus marked, as any subject in the language, for the nominative case.

(8) Hayyá! Wóna-n ke-'is-sunta-'e hashsh-oommí=g-u

INTJ first.OBL-N rise-CAUS1-2S.PURP.DS-1S.O want-1S.PFV.REL $=$ G-M.NOM

hittig-u-ta

SIM1 P DEM-F.PRED-F.COP2

'Perfect! The way I wanted you to draw (lit. make rise) (the picture) right from the start is (exactly) like this.' (QL 2018)

The standard marking function of $=g$ is certainly an extension of its manner nominalising function, but the boundary between these two functions is sometimes hard to draw. While (5) permits a more literal manner translation as 'I jumped up like (= in the manner of) a man whom thunder had struck', (6) can mean that the speaker does something in the addressee's way or that the speaker is similar to the addressee in appearance and character. For more details on the multifunctionality of $=g$ see Treis (2017).

\section{EQUALITY}

Kambaata distinguishes between two equative constructions, which differ with respect to their frequency as well as their origin, multifunctionality and degree of grammaticalisation of the standard marker. The first, most common equative construction follows the above-mentioned manner schema: 'COMPAREE is PARAMETER (in) STANDARD's manner', i.e. this equative construction differs from the similative construction $(\$ 3)$ only with respect to the overt expression of the parameter of comparison. The parameter can be expressed by an adjective, e.g. 'strong' in (9) and 'beautiful' in (10), a property verb, e.g. laaf- 'be(come) soft', or a property ideophone, e.g. gambáll=y- 'be(come) black'.

(9) Zoobb-ée $=\boldsymbol{g}$ - $a$ xalig-á ik-kumbóochch lion-M.GEN=G-M.ACC/OBL strong-M.ACC become-2S.NREL.ABL urr-ú-' kad-dókkoont

front_yard-F.ACC-1S.POSS step-2S.APP

'Unless you are as strong as a lion, don't dare to step into my front yard!' (K89: 6.124 corrDW) 
(10) Án tees-ó caf-í doo'll-ó=g-a

1S.NOM now-F.GEN swamp-M.GEN type_of_bird-F.GEN=G-M.ACC/OBL

dan-aam-íta m-íi ih-áam-b̄a'a y-itóo'

beauty-AAM-F.ACC what-M.DAT become-1S.IPV-NEG1 say-3F.PFV

“"Why am I not as beautiful as that flamingo?”, she said.' (TD2016-02-11_001)

The second, less common equative construction is syntactically parallel to the first but uses another standard marker, namely qax-á 'amount, extent'. This construction follows the schema 'COMPAREE is PARAMETER (to) STANDARD's amount/extent'. It is mostly used with measurable parameters, e.g. in expressions of equality of size, height, distance or amount (11).

(11) Ā'á'̄a Caakkís-u Da'llis-ó qax-á qeráa'rr-u-a-ba'a INTJ PN-M.NOM PN-M.GEN extent-M.ACC tall-M.PRED-M.COP2-NEG1

'No, Caakkiso isn't as tall as Da'lliso.' (Fn_DW2014-12-10_Dialogue)

A parameter 'tallness' does, however, not exclude the use of the standard marker $=g$ 'manner'. Thus Da'llis-ó qax-á lit. 'to Da'lliso's extent' in (11) could be replaced by $D a$ 'llis- $\delta=g-a$ lit. 'in Da'lliso's manner'. The replacement results in a slight meaning difference: While the 'extent'-equative expresses that the compared entities have the same height, the 'manner'-equative expresses that both are (relatively) tall but not necessarily of exactly the same height, e.g. a little boy could be said to be tall "in his father's manner", if both he and his father were fairly tall in their respective peer groups but, of course, not equally tall.

The 'extent'-equative is rarely attested with non-measurable (or not commonly measured) qualities in natural discourse..$^{10}$ The only example in my text corpus is (12), in which the beauty of pictures is compared.

(12) M-íha-am-mat kánn misil-i qax-á what-M.DAT-COP3-? A_DEM1.M.OBL picture-M.GEN extent-M.ACC cúlu $=a$ '-anó-na - maalal-siis-anó

beautiful.IDEO=do-3M.IPV.REL-CRD surprise-CAUS2-3M.IPV.REL wól-u misill-u kánn maxaaf-i aaz-éen other-M.NOM picture-M.NOM A DEM1.M.OBL book-M.GEN inside-M.LOC yóo-ba'i-i?

COP1.3-NEG1-NMZ1.M.NOM

'Why are there no other pictures in this book that are as beautiful and as impressive as this picture?' (QL 2018)

According to native speakers, the use of qax-á implies that standard and comparee are identical with respect to an objectively evaluable, measurable parameter. In (12) the use of qax-á was considered appropriate because the speaker had elaborated in the preceding context according to which criteria he judged a picture beautiful and that the beauty thus became objectifiable.

${ }^{10} \mathrm{Cf}$. the use of special equative markers with dimensional adjectives in Balkan languages (Haspelmath \& Buchholz 1998: 300f). 
If no overt parameter of comparison is expressed in the clause or in the preceding linguistic context, constructions with qax-á are interpreted as expressing equality in size, height, distance and amount (13). $\begin{array}{llll}\text { (13) } K u & \text { bóos- } u & \text { hikkánni-a } & \text { qáx-a } \\ \text { A DEM1.M.NOM } & \text { water pot-M.NOM } & \text { A DEM2.M.GEN-M.COP2 } & \text { extent-M.PRED }\end{array}$ 'This water pot is as (implicit parameter: big) as that one.' (But not e.g. *'This water pot is as (implicit parameter: beautiful) as that one.') (Fn_DW2004)

In the case of $q a x-\dot{a}$ 'amount, extent' it is difficult to justify speaking of a "standard marker" in the sense of "standard-marking grammeme", because the noun - unlike the enclitic $=g-$ does not seem to have undergone grammaticalisation. It is still widely used as a full noun and has retained its full case-marking potential. It is, however, semantically fairly broad and can, depending on the context, be translated as 'amount (14), quantity, number; volume, contents; size, height, length, circumference; (spatial) distance, extent, limit; (temporal) distance, period of time, while (15); rate, degree (16)'.
(14) Kánn qax-íichch m-á aass-áan-ke-la?
A DEM1.M.OBL amount-M.ABL what-M.ACC give-1S.IPV-2S.O-MIT
'What can I give you from this amount? (i.e. It is too small to share.)' (Fn_DW2004)
(15) (...) qah-ú qax-á egérr fóol-u-s small-M.ACC amount-M.ACC wait.3M.PCO soul-M.NOM-3M.POSS fúlli-yan reh-ee'iichch (...) leave.3M.PCO-DS die-3M.PFV.REL.ABL
'(...) one waits a little while, and when the soul has left (the bull) and it has died (...).' (TH_Tä2003-09-26)

(16) Gaaz-i hir-at ammóo abbis-s barg-itán

$\begin{array}{llll}\text { Gaaz-l } & \text { hir-at } & \text { ammoo abbis-s } & \text { barg-itán } \\ \text { fuel-M.GEN price-F.NOM but } & \text { bexceed-3F.PCO add-3F.ICO } \\ \text { gal-táyyoo=bikkíha } & \text { zabb-i-sí } & \text { hir-atí-i } \\ \text { spend_time-3F.PROG.REL=REAS3 } & \text { medicine-M.GEN-DEF } & \text { price-F.NOM-ADD } \\ \text { hikkanní } & \text { qax-ánka } & \text { le'-áyyoo'u } & \end{array}$
$\mathrm{P}$ DEM2.M.GEN amount-M.ACC $<\mathrm{N}>$ grow-3F.PROG

' $\bar{B}$ ecause the price of fuel is rising excessively, the price of medicine is rising at that (fuel's) rate/to that degree.' (K89: 7.155)

Apart from the noun qax-á 'amount, extent', Kambaata also has a case-/genderagreeing adjective qax-á(ta) 'as much as', which is only used in attributive quantitative equative constructions (17) (cf. Haspelmath \& Buchholz 1998: 298301).
(17) Dandee-toontí
be able-2F.PFV
qax-áta
xink-úta
be_able-2F.PFV.REL as_much_as-F.ACC riddle-F.ACC
'Write down as many riddles as you can (...).' (K89: 4.81)
xáaf- $f(\ldots)$
write-2S.PCO 


\section{NON-SIMILATIVE AND NON-EQUATIVE DEMONSTRATIVES}

Before analysing similative and equative demonstratives in the next section, it will be helpful to give a general introduction into the Kambaata demonstrative system. As is typical of demonstratives cross-linguistically (see Diessel 2003), Kambaata demonstratives cross-cut the boundaries of several word classes. Demonstrative adjectives have the typical adjectival 3-case/2-gender system to mark agreement with the head of an NP. Number is not marked. Unlike true adjectives $(\S 2)$, demonstrative adjectives cannot become NP heads if the head noun is dropped. ${ }^{11}$ Demonstrative adjectives distinguish between four deictic dimensions: proximal, medial, contrastive and distal (Treis 2008: 322-26). For reasons of space, only the case paradigm of the medial demonstrative is provided in Table $4 .{ }^{12}$ Compare Table 4 with the adjectival paradigm in Table 3.

\begin{tabular}{|l|l|l|}
\hline & $\mathrm{M}$ & $\mathrm{F}$ \\
\hline Accusative & hikka & hitta \\
\hline Nominative & híkku & hítt \\
\hline Oblique & híkka $\sim \operatorname{hikkán}(n)$ & hítta $\sim \operatorname{hittán}(n)$ \\
\hline
\end{tabular}

Table 4. Medial demonstrative adjectives ('that')

Demonstrative pronouns have a 10-case system (Table 5, compare with Table 2). In all cases except the oblique and the directional, the pronouns are marked for gender and number. The distinction between masculine and feminine plural forms is a noteworthy feature of the demonstrative paradigm, because nowhere else does the language make a gender distinction in the plural. The pronouns can be used to refer to persons, animals, objects and events (18); the oblique and the directional forms are exclusively used for places: e.g. hikkánne 'there (at medium distance)' (19) and hikkabá 'to there (at medium distance)'. Demonstrative pronouns differentiate four deictic dimensions (Treis 2008: 360-381), but only the medial forms are provided for illustrative purposes in Table 5.13

\begin{tabular}{|l|l|l|l|l|}
\hline & M & F & M.PL & F.PL \\
\hline Accusative & hikkáan & hittáan & hikkará & hittará \\
\hline Nominative & hikkúun & hittíin & hikkurú & hittirú \\
\hline Genitive & hikkanní & hittanné & hikkarrí & hittarrí \\
\hline Dative & hikkanníi(ha) & hittannée $($ ha $)$ & hikkarrí(ha) & hittarrí(ha) \\
\hline Ablative & hikkanníichch & hittannéechch & hikkarríchch & hittarríichch \\
\hline $\begin{array}{l}\text { Instrumental- } \\
\text { Comitative-Perlative }\end{array}$ & hikkanníin & hittannéen & hikkarríin & hittarríin \\
\hline Locative & hikkannéen & hittannéen & hikkarráan & hittarráan \\
\hline
\end{tabular}

${ }^{11}$ Instead demonstrative pronouns (Table 5) are used.

12 Several examples in this paper illustrate the use of demonstrative adjectives (glossed A_DEM), see (12-14) and (47) for proximal demonstratives (A_DEM1) and (2), (13) and (23) for medial demonstratives (A DEM2).

13 The following examples contain demonstrative pronouns (glossed P_DEM): (16) and (19) contain medial demonstratives (P_DEM2), (60) a proximal demonstrative (P_DEM1). 


\begin{tabular}{|l|l|l|l|l|}
\hline Oblique & hikkánne & - & - & - \\
\hline Directional & hikkabá & - & - & - \\
\hline Predicative-COP3 & hikkánne-et & hittánne-et & hikkárra-at & hittárra-at \\
\hline
\end{tabular}

Table 5. Medial demonstrative pronouns ('that one')

(18) Hikkúun-si-n mán-ch-u-a-ba'a

P_DEM2.M.NOM-DEF-N person-SG-M.PRED-M.COP2-NEG1

hittíin qaa'-íchch-u-ta

P DEM2.F.NOM mushroom-SG-F.PRED-F.COP2

'That's not a man, that's a mushroom.' (QL 2018)

Presentative demonstratives (Table 6) do not match any other word class in Kambaata. They are only used in predicative function (19), serving to point out or present entities (which are expressed as nominative subjects) or, if used in isolation, calling the addressee's attention to a preceding or following utterance. Their use, but of course not their morphology, is comparable to French voilà (see Treis forthcoming for details). Like demonstrative pronouns they are marked for two genders and two numbers, but in contrast to demonstrative pronouns, they only distinguish three deictic dimensions (proximal, medial, distal).

\begin{tabular}{|l|l|l|l|}
\hline $\mathrm{M}$ & $\mathrm{F}$ & M.PL & F.PL \\
\hline hikku'nn & hitti'nn & hikkurú'nn & hittiru'nn \\
$\sim$ hikku'nniin & $\sim$ hitti'nníin & $\sim$ hikkuru'nníin & $\sim$ hittiru'nníin \\
\hline
\end{tabular}

Table 6. Medial presentative demonstratives ('there it is')

(19) Hittínni-bay

hikkánne haqquuchch-i fagaar-áan

PRES DEM2.F.NOM-CONF.Q P DEM2.M.OBL tree.SG-M.GEN bottom-F.LOC

uurr-itee' $i$-i?

stand-3F.PRF.REL-NMZ1.M.NOM

(Context: A hen has disappeared and mother and daughter are looking for it. Suddenly the daughter spots the hen.) 'There she (= the hen) is, isn't she standing there under the tree?' (Fn DW2016-04-01)

The similative and equative demonstratives discussed in the next section cannot be subsumed under any one of these morphosyntactically defined demonstrative types. Most notably, similative and equative demonstratives do not distinguish any deictic dimensions. Morphosyntactically, they form a heterogeneous class. The similative demonstratives discussed in \$6.1, hitt-íta 'like this' and hittig-úta 'id.', share morphological features with (pro)nouns, but they only inflect for a reduced number of cases. The similative demonstratives of $\$ 6.2$, hittigoon-á $(-t a)$ 'such, of this kind' and hittigaam-ú/-ita 'id.' can be categorised - without reservation - into the adjective word class, more precisely as derived adjectives. The equative demonstratives kank-á(ta) 'this much/many, to this degree' and hibank-á(ta) 'id.' discussed in $\$ 6.3$ are also clearly adjectival in nature, as their agreement potential shows. ${ }^{14}$

14 The Kambaata similative and equative demonstratives would be better translated as 'like this/that/that far', 'of this/that/that kind', 'to this/that/that far degree' and 'of this/that/that 


\section{SIMILATIVE AND EQUATIVE DEMONSTRATIVES}

\subsection{Similative demonstrative pronouns}

Kambaata has two similative demonstrative pronouns that are primarily used in adverbial function: hitt-ita 'like this' and hittig-úta 'id.'. They have a restricted case-marking potential. Although the similative demonstrative pronouns are phonologically similar to the various feminine medial demonstratives (Table 4-6) - see the characteristic hitt-sequence of phonemes - they are also used to identify manners of actions that are carried out in proximity or at a distance. They could be said to have generalised a medial form as the default. ${ }^{15}$

The pronoun hitt-ita 'like this' has the appearance of a feminine accusative noun of declension F2a (compare Table 2), but apart from a predicative form, hitt-i (22), no other case form exists. It is nevertheless justified to interpret the ending -ita as an accusative morpheme, because this case does not only mark direct objects but also nominals in adverbial function (Treis 2008: 117f). In (20) the demonstrative pronoun is used exophorically and refers to the horse's way of standing, as observable in the external world and, possibly, as pointed out gesturally by the speaker.

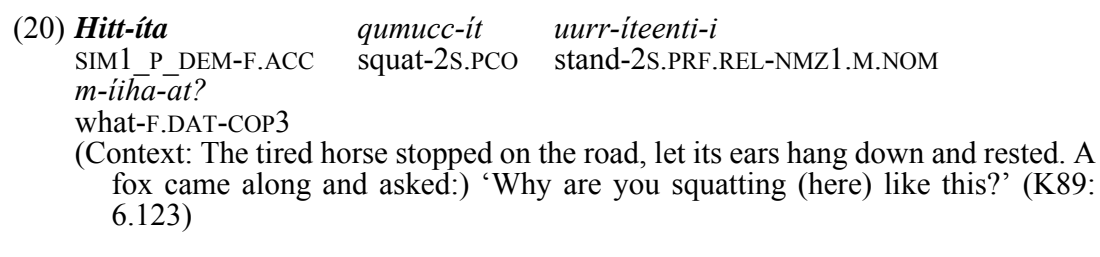

Hitt-ita is used endophorically with reference to a way of doing (manner) (20) or a situation that has been mentioned earlier (anaphoric: 21 ) or is mentioned later in the linguistic context (cataphoric: 22 ).
(21) Tah-íchch-u dángo hitt-íta afuu'll-it
fly-SG-M.NOM suddenly SIM1 P DEM-F.ACC sit-3F.PCO
zug-gáni-yan waall- $\bar{o}=d a(\ldots)$
lie in ambush-3F.ICO-DS come-3M.PFV.REL $=$ COND

(Context: Speaker has described how a chameleon lies in ambush.) 'When a fly comes suddenly while it (= the chameleon) is lying (lit. sitting) in ambush like this (...).' (TD2016-02-11_001)

far quantity'. It is only for convenience's sake that the proximal translation is used throughout this paper.

15 In two languages that are closely related to Kambaata, manner deictics keep a deictic opposition: Libido, a language with three deictic oppositions, distinguishes between a proximal and medial manner deictic (Crass 2017: 413). Sidaama, a language with four deictic oppositions, has two different manner deictics, togo 'like this' (proximal) and hatto 'like that' (mesioproximal) (Dukamo 2014). As Kambaata hitt-ita, the manner deictics in these languages are non-compositional. 
(22) Hítt-i-ta,

kárag, (...)

SIM1 P DEM-F.PRED-F.COP2 pay attention.2S.IMP

'It is like this, pay attention (to what follows), (...).' (Fn_DW2017-03-04)

The similative demonstrative pronoun can also be used to refer to the contents (and not the manner) of a reported speaking event (23). Furthermore, it is commonly used cataphorically or anaphorically, together with the verb $y$ - 'say', to introduce or to close chunks of direct speech in narratives, as illustrated in (24).

\begin{tabular}{|c|c|c|}
\hline $\begin{array}{l}\text { DEM2.M.OBL } \\
n i n-i-s i-j\end{array}$ & PN-M.GEN & $\begin{array}{l}\text { house-M.LOC } \\
\text { xúud-deent }\end{array}$ \\
\hline
\end{tabular} contradicts him.) 'You would not say this/like this (here: *in this way) if you had seen the amenities in that house of Duuballa's and the house itself.' (Fn_DW2014-12-10)
(24) (...) qamál-ch-ut maccoocc-itán egér-t hitt-íta monkey-SG-F.NOM hear-3F.ICO stay-3F.PCO SIM1_P_DEM-F.ACC y-itóo'u: “(...)" say-3F.PFV
' (...) the monkey listened and (then) said this/like this (here: *in this way, but: as follows): “...”.' (K89: 4.77)

Sequences of hitt-ita 'like this' and a form of $a$ '- 'do'16 can fuse into one phonological word. The inflectional suffix is lost and the merger results in a transitive similative demonstrative verb hitt $=a$ '- 'do like this' ${ }^{17}$

(25) Agúr Hádd-e, hittíg-o-ob-ba'a,

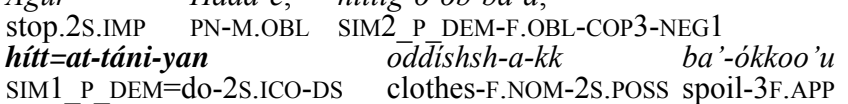

(Context: Speaker sees Hadde wiping his nose on his sleeve.) 'Stop, Hadde, it's not like this (/one doesn't do like this), if you do it like this, your clothes run the risk of becoming dirty.' (K89: 4.17)

In my corpus, there are also two instances of an intransitive demonstrative verb hitt $=y$ - 'do like this' (intr.). One example comes from a written text, the other from my field notes. The intransitive form consists of a demonstrative element and the verb $y$ - 'say'. But whereas the transitive hitt $=a$ '- 'do like this (tr.)' (25) can always be paraphrased by hitt-ita $a$ '- 'do like this', the intransitive hitt=y- can no longer

${ }^{16}$ The verb $a$ '- 'do' has two alternating stems: $a t$ - in front of $t$-initial inflectional morphemes and $a^{\prime}$ - elsewhere.

17 See Guérin (2015) for a cross-linguistic study of demonstrative verbs. 
be replaced by hitt-ita $y$ - 'say like this' in (26). The verb $y$ - 'say' in the similative demonstrative is desemanticised and serves only as a host for the verbal inflection. ${ }^{18}$

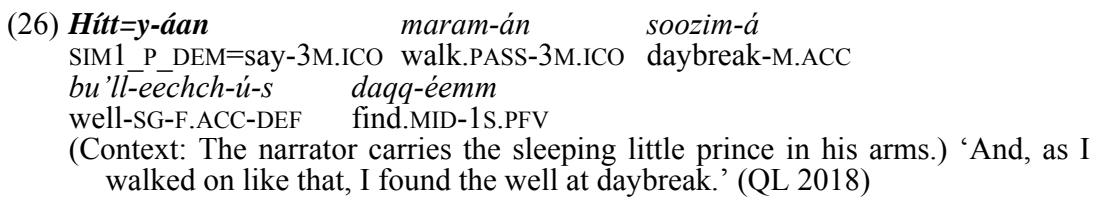

Furthermore, the similative demonstrative pronoun has fused with perfective converb or main verb forms of the verb ih- 'be(come)'. The formal change has come along with a semantic change: the fused forms have developed into a contrastive connective 'but'. The most common realisation of this connective in my corpus is hitt=ikk<*hitt-ita ikk (SIM1_P_DEM-F.ACC be.1/3.PCO) (27).

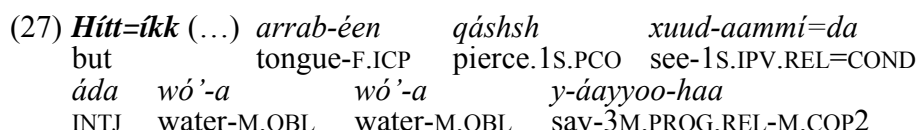

(Context: Sentence (1c) above). 'But when I tasted the oranges (after I had bought them from her), they were watery (lit. said "water, water").' (Fn_2014-1224_Dialogue)

We now turn to the second similative demonstrative pronoun in Kambaata, hittigúta (SIM2_P_DEM) 'like this'. It is largely synonymous with hitt-ita (SIM1_P_DEM), but there are important formal differences. Hittig-úta carries an accusative ending of a different feminine declension, namely F3a in -ú-ta (Treis 2008: 103). Synchronically, its stem cannot be segmented any further, but - viewed from a diachronic perspective - it contains a manner morph $* g,{ }^{19}$ which must have been combined with a demonstrative adjective in earlier times. Subsequently, the morpheme boundary between the demonstrative and the manner morph has blurred and the result is today's unanalysable similative demonstrative pronoun. It is difficult to find contexts in which hitt-ita (SIM1_P_DEM) and hittig-úta (SIM2_P_DEM) are not free variants of each other. Hittig-úta, too, can be used exophorically (25) and endophorically (28-29). It is used in adverbial function (28) or, in the form hittíg- $u$ (29), in predicative function (see also (8) above)).

18 The same can be observed for Kambaata ideophones, which all consist of an morphologically invariant lexeme plus a 'say' or 'do' verb, e.g. lácc $=y$ - 'be/do slowly (intr.)' and lácc $=a$ '- 'do slowly (tr.)'. As the morphological makeup of the similative demonstratives in (25) and (26) is similar to that of ideophones, one could also consider speaking of similative demonstrative ideophones rather than verbs.

19 The manner nominaliser $=g$ discussed in $\S 3$ is very likely to be etymologically related to the $* g$ in hittig-úta. But note that $=g$ is followed by masculine, and $* g$ by feminine case/gender morphology. 
(28) Uull-á al-éen hor-áani-n hittig-úta earth-F.GEN top-M.LOC all-F.LOC-N SIM2_P_DEM-F.ACC

biix-am-úmb- $o=g-a \quad$ qorab-eennó $=r-u$

break-PASS-3M.NREL-M.OBL $=\mathrm{G}-\mathrm{OBL}$ take_care-3HON.IPV.REL=NMZ.P-M.NOM he'-umb-ú-u agújj-o-'e

exist-3M.NREL-NMZ1.M.NOM seem-3M.PFV-1S.O

(Context: Speaker described how he carried the Little Prince in his arms like a very fragile treasure.) 'It seemed to me that there was nobody on earth who had to be taken care of in the same way for him not to break (i.e. he was the most fragile person on earth).' (QL 2018)

(29) Hittíg-u-ta

SIM2 P DEM-F.PRED-F.COP2

dag-a $\bar{q} \bar{q}-$ amm-oommi $=g-u$

knOw-MID-PASS-1S.PFV.REL $=$ G-M.NOM

(Context: Speaker has told in detail the events surrounding the first meeting with the little prince.) 'It is like this that I came to know the little prince for the first time.' (QL 2018)

Hittig-úta allows for two more adverbial case forms, the instrumental-comitativeperlative hittig-óon (30) and the oblique hittíg-o (31). ${ }^{20}$

(30) Hittig-óon

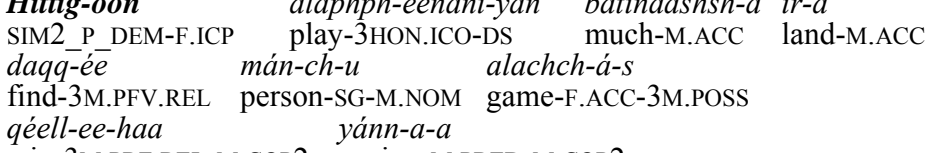

qéell-ee-haa

yánn- $a-a$

win-3M.PRF.REL-M.COP2 saying-M.PRED-M.COP2

(Context: Author explains the rules of a riddling competition) 'When playing like this, the person who has got most (lit. much) land is said to have won the game.' (GH: 144)

$\begin{array}{lll}\text { (31) Hittíg-o } & \text { dasán-u-’ } & \text { mur-ámmi-yan (...) } \\ \text { SIM2 } & \text { tail-M.NOM-1S.POSS } & \text { cut-PASS.3M.PCO-DS }\end{array}$

(Context: Speaker explains how he lost his tail.) 'After my tail was cut off like this ...' (NJ4.32)

In contexts such as (30-31), the ICP form hittig-óon and the oblique form hittíg-o are functionally equivalent to the accusative form hittig-úta. There is, however, one context in which the accusative form hittig-úta is very frequent and in which the ICP and oblique forms are unattested, namely in anaphoric or cataphoric reference to the contents of directly quoted speech (32).

${ }^{20}$ See also (25). 


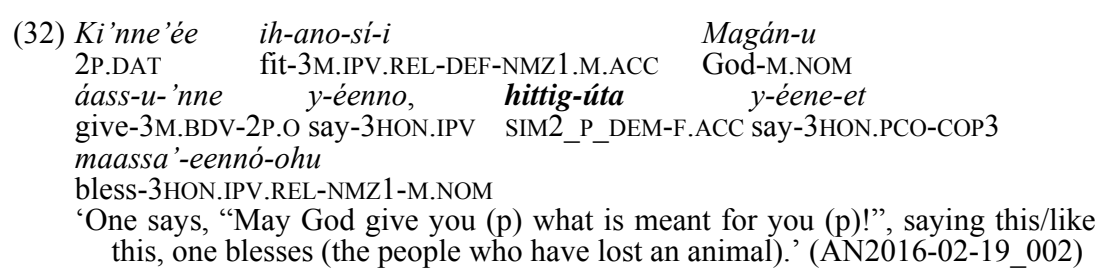

A survey of the occurrences of hitt-ita (SIM1_P_DEM) and hittig-úta (SIM2_P_DEM) in my corpus shows that they are attested in very similar contexts. Native speakers usually accept replacing one by the other when examples from texts are checked in which the pronouns are used as true manner deictics or quotatives. In more lexicalised or grammaticalised forms, however, the pronouns cannot easily be swapped. Both pronouns have, for instance, developed special meanings in combination with the pragmatically determined $-n$-morpheme. The $-n$-morpheme is very common in natural discourse, see e.g. hor-áani- $n$ all-M.LOC-N 'on all' in (28), and is by no means restricted to similative demonstrative pronouns but can be attached to different kinds of constituents, i.e. to non-demonstrative (pro)noun phrases, subordinate clauses, sentence-final main verbs and non-verbal predicates; sometimes $-n$ is even used several times in one sentence. The morpheme can very vaguely be characterised as having a highlighting or emphasising function; ${ }^{21}$ its precise pragmatic meaning is, however, still to be properly investigated. Depending on the morphological structure of its host, it is either suffixed or infixed (for details see Treis 2008: 220-27). Hitt-inta, which results from a combination of hitt-ita 'like this' (SIM1_P_DEM) + $-n$, is used in two separate functions. Firstly, it is used, as expected, as an emphatic similative demonstrative (33).

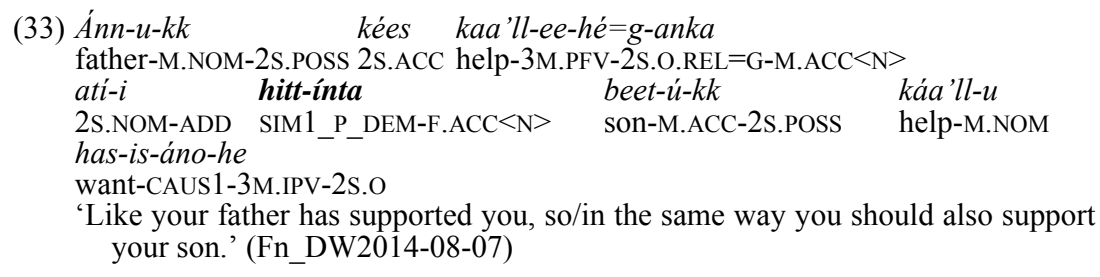

Secondly, it is used with the meaning 'simply, empty-handed, unfinished, without use, without fuss, without any addition, with no excuses, at no charge' (34). This use is clearly non-deictic, and speakers paraphrase hitt-ita in this use with xall-á 'only, just' or on-á 'empty'.

\footnotetext{
${ }^{21}$ In descriptions of the languages most closely related to Kambaata, it is labelled an "emphasis marker" (Schneider-Blum 2007: 136) in Alaaba and analyzed as a definiteness suffix as well as a focus and emphasis marker in K'abeena (Crass 2005: 120f, 254f).
} 

(34) Gotaangót-e it-taante-'é=da hitt-inta PN_hyena-F/M.OBL eat-2S.IPV-1S.O.REL=COND SIM1_P_DEM-F.ACC $<\mathrm{N}>$ it-e-'e, $\quad y$-itóo'u harrúuchch-ut eat-2S.IMP-1s.o say-3F.PFV donkey.SG-F.NOM "(My dear) Hyena, if you want to eat me, eat me with no excuses!" said the donkey jenny.' (A\&A 2017)

It is only in its deictic function (33) that hitt-inta can be replaced by hittig-únta, which is the corresponding emphatic form of hittig-uita (SIM2 P DEM). Native speakers do not accept the substitution of a non-deictically used $\bar{h}$ itt-inta "with no excuses' (34) by hittig-únta. Interestingly, hittig-únta also allows for a non-deictic use, albeit a use that is different from that of hitt-inta. The texts show that hittigúnta is a ubiquitous discourse particle, which is mostly translatable as 'also, too, and'. It has developed into an inter-phrasal (35) or inter-sentential coordinating connective (36). ${ }^{22}$
(35) Uull-á serekket-aan-ch-ú $\quad y$-ú báar-u, lág-u, town-M.NOM mountain-M.NOM SIM2_P_DEM-F.ACC $<$ N $>$ earth-F.GEN desert-M.NOM uull-á al-éen hakkánne he'-áa-ndo qorm-í earth-F.GEN top-M.LOC where.M.OBL exist-3F.IPV-Q be_wise-3M.PCO dag-anó man-ch-ú $\quad y-u ́-a$
know-3M.IPV.REL person-SG-M.ACC Say-M.PRED-M.COP2
'A geographer is a wise man who knows where the seas, rivers, towns, mountains and deserts are found on Earth (lit. "Saying "a geographer" is saying "a wise man who ..."').' (QL 2018)

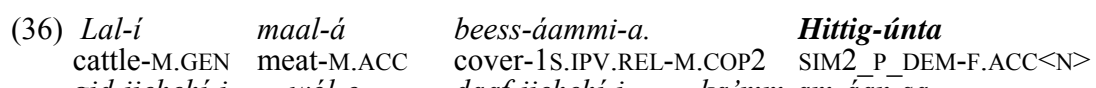 gid-iichchí-i wól-o daaf-iichchí-i ka'mm-am-áan-sa cold-M.ABL-ADD other-M.OBL danger-M.ABL-ADD forbid.MID-PASS-1S.IPV-3P.O (In a story a leather skin says:) 'I cover the cattle's flesh. And I protect them (= the cattle) from cold and other dangers, too.' (K89: 3.47)

To conclude the section on manner demonstratives, it only remains to mention that the predicative form of hittig-úta (but not hitt-ita) is used as an expression of affirmation or confirmation (37). ${ }^{23}$

(37) Mat-ú mat-íin usu'rr-ám-u-a? - Hittíg-u-ta. one-M.ACC one-M.ICP tie.MID-PASS-M.PRED-M.COP2 SIM2_P_DEM-F.PRED-F.COP2 (Context: The little prince is not sure whether he has understood the narrator's explanation of what tame means. He requests a confirmation.) '(Does it mean) to tie one to the other?' - (The narrator confirms.) 'Yes.' (QL 2018)

22 König (2015: 45) mentions several European languages in which manner demonstratives have developed into coordinating conjunctions via an intermediate stage of additive focus markers. This intermediate stage is not attested for hittig-únta.

${ }^{23}$ See König $(2015,2017)$ for a discussion on the development of manner demonstratives into affirmative particles in European languages. 


\subsection{Similative demonstrative adjectives}

Kambaata has two similative demonstrative adjectives, hittigoon-á(ta) (SIM1_A_DEM) 'such, of this kind' and hittigaam-ú/-ita (SIM2_A_DEM) 'id.'. They express similarity between a target of demonstration and the referent of the noun phrase in which they occur; they identify a quality or a kind. The two demonstratives share most morphosyntactic features of true adjectives. ${ }^{24}$ When used as modifiers in a noun phrase, they show case and gender agreement with the head noun. For this purpose, they are marked for three cases and two genders (Table 7) - as any other Kambaata adjective (Table 3).

\begin{tabular}{|l|l|l|l|l|}
\hline & \multicolumn{2}{|l|}{$\begin{array}{l}\text { hittigoon-á(ta) } \\
\text { 'such, of this kind' }\end{array}$} & \multicolumn{2}{l|}{$\begin{array}{l}\text { hittigaam-ú/-ita } \\
\text { 'such, of this kind' }\end{array}$} \\
\hline & $\mathrm{M}$ & $\mathrm{F}$ & $\mathrm{M}$ & $\mathrm{F}$ \\
\hline Accusative & hittigoon-á & hittigoon-áta & hittigaam-ú & hittigaam-íta \\
\hline Nominative & hittigóon- $u$ & hittigóon-at & hittigáam-u & hittigáam-it \\
\hline Oblique & hittigóon- $a(a)$ & hittigóon-a(ta) & $\begin{array}{l}\text { hittigáam-o } \\
\sim \text { hittigáam-ua }\end{array}$ & $\begin{array}{l}\text { hittigáam-e } \\
\sim \text { hittigáam-ita }\end{array}$ \\
\hline
\end{tabular}

Table 7. Case/gender paradigm of the similative demonstrative adjectives

In (38) the similative demonstrative adjective agrees with a feminine, and in (39) with a masculine accusative noun, maass-áta 'blessing' and xah-á 'thing, deed', respectively. In (38), the demonstrative targets the directly quoted exemplary blessing in the preceding clause; in (39) it targets the antecedent 'adultery'.

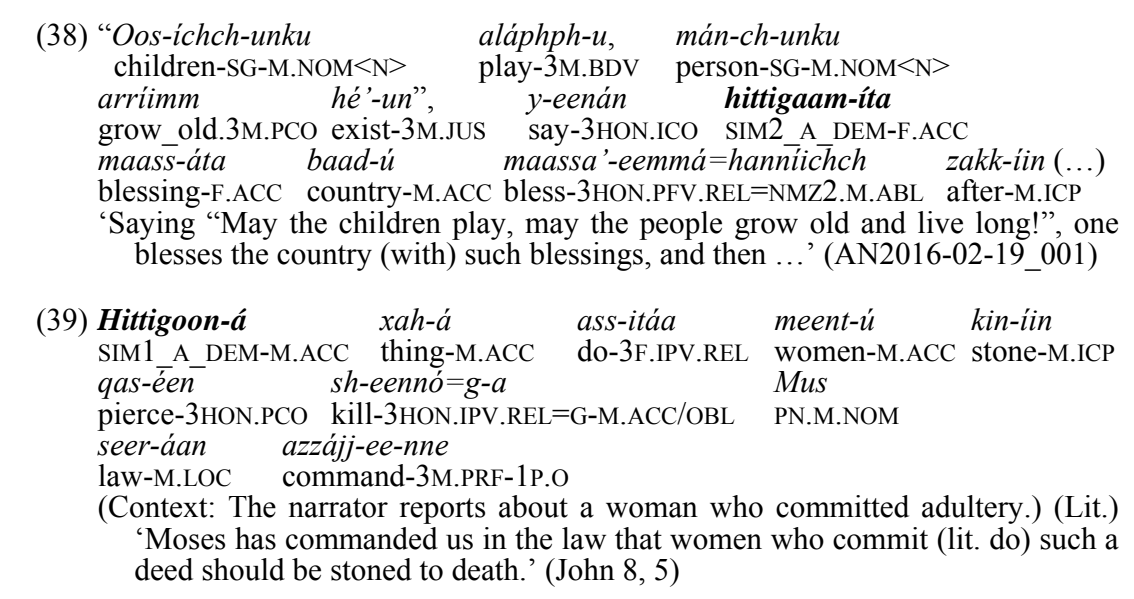

24 The two similative demonstrative adjectives are to be categorised in the subclass of derived adjectives, as argued below. Derived adjectives, unlike true adjectives, have no direct verbal counterparts (Treis 2008: 268-73). 
If the head noun is left unexpressed the similative demonstrative adjective can become the NP head and is then marked for all nine nominal cases (recall Table 2). In (40), the target of demonstration is the quality/kind of three-legged table in the preceding sentence. See also the predicative use of the adjective in (41). Hittigoon$a ́(t a)$ is used anaphorically (38-40) and exophorically (41).

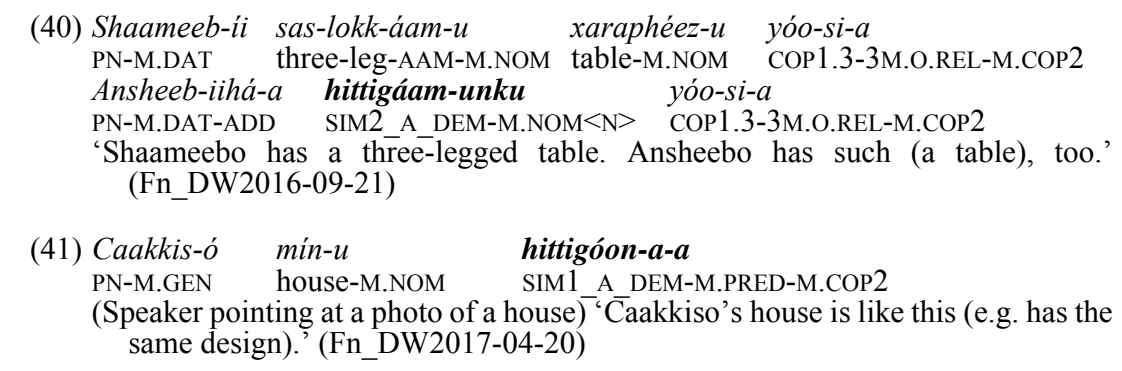

The simplex similative demonstrative pronoun hitt-ita 'like this' (§6.1) can be paraphrased by an adverbial phrase consisting of a similative demonstrative adjective plus a noun 'way, manner' or the manner nominaliser $=g$. In (42) we find hittigóon-aa woqqéeneet 'it is in such a way', a focused ICP phrase, which can be replaced - according to native speaker judgments - by hitt-i-ta (SIM1_P_DEMF.PRED-COP2) 'it is like this' without any change in meaning. Likewise, the adverbial phrase hittigóon-aa=g-iin lit. 'through such a way' (43), which is especially common in the translations of biblical texts, can stand in for the simplex similative demonstrative pronoun hitt-ita 'like this'.
(42) Hittigóon-aa woqq-éene-et $\begin{array}{lcll}\text { SIM1_A_DEM-M.OBL } & \text { way-M.ICP-COP3 } & \text { fig tree-F.GEN tree-M.NOM } \\ \text { is } & \text { he'-anó } & \text { plaaneet-i } i & \text { al-éen iill-ishsh-ó }\end{array}$ $\begin{array}{ll}\text { 3M.NOM live-3M.IPV.REL planet-M.GEN } & \text { top-M.LOC arrive-CAUS1-3M.PFV.REL } \\ \text { haww- } i=\text { tannee } & \text { dag-óta }\end{array}$
problem-M.GEN=about know-1S.PURP.SS be able-1S.PFV.REL-NMZ1-M.NOM
(Context: The narrator was able to learn details about the little prince's planet and his journey in their conversations. He learned many things by chance.) 'It was in this way (i.e. by chance) that I learned, on the third day, about the catastrophe that the baobabs (lit. fig trees) had caused on the planet where he was living.' (QL 2018)

(43) Hoolam-áta j-áata isso'óo ann-áakk-ati-i am-áakk-ati-i much-F.ACC time-F.ACC 3P.GEN father-PL2-F.NOM-ADD mother-PL2-F.NOM-ADD isso'óota hittigóon-aa=gg-iin le'-is-sóo=tannéeha-at 3P.ACC SIM1 A DEM-M.OBL=G-M.ICP grow-CAUS1-3F.PFV.REL=REAS1-COP3

(Context: Today one can often hear parents swearing at their children. Why do they do this?) 'It is often because their own fathers and mothers have raised them in such a way.' (B\&Y: 20) 
I am unable to pinpoint a meaning difference between the similative demonstrative adjectives hittigoon-á(ta) and hittigaam-ú/-ita; they occur in identical contexts and seem to be true synonyms. ${ }^{25}$ They also have a similar morphological makeup: Both adjectives are derived from the similative demonstrative pronoun hittig-úta 'like this' (SIM2_P_DEM) (§6.1). The adjective hittig-aam-úl-ita contains the proprietive morpheme -aam (glossed AAM) - a very productive derivational morpheme that generates adjectives with the meaning 'having $\mathrm{N}$, with $\mathrm{N}$, of $\mathrm{N}$ ' on the basis of nouns, e.g. fool-i 'soul, life' > fool-aam-úl-ita '(a)live, animate' and xud-á 'climbing plant' > xuud-aam-ú-ita 'with climbing plants (e.g. a fence)', ${ }^{26}$ see Treis (2008: 274-77) for details. In analogy, hittig-oon-á(ta) is segmentable into a stem hittig-(SIM2_P_DEM), a derivational morpheme -oon and an adjectival case/gender morpheme. However, the morpheme -oon is not attested anywhere else in the language.

\subsection{Equative demonstrative adjectives}

Kambaata has two equative demonstrative adjectives, kank-á(ta) (EQ1 A DEM) 'this much/many, to this degree' and hibank-á $(t a)^{27}$ (EQ2_A_DEM) 'id.', which identify a degree of a property or an amount that is expressed in the linguistic context or observable in the external world. The adjectival case/gender paradigm of the equative demonstratives is provided in Table 8.

\begin{tabular}{|c|c|c|c|c|}
\hline & \multicolumn{2}{|c|}{$\begin{array}{l}\text { kank-á(ta) 'this much/ } \\
\text { many, to this degree' }\end{array}$} & \multicolumn{2}{|c|}{$\begin{array}{l}\text { hibank-á/-áta 'this much/ } \\
\text { many, to this degree' }\end{array}$} \\
\hline & $\mathrm{M}$ & $\mathrm{F}$ & $\mathrm{M}$ & $\mathrm{F}$ \\
\hline Accusative & kank-á & kank-áta & hibank-á & hibank-áta \\
\hline Nominative & kánk-u & kánk-at & hibánk-u & hibánk-at \\
\hline Oblique & kánk-a(a) & kánk-a(ta) & hibánk-a $(a)$ & hibánk-a(ta) \\
\hline
\end{tabular}

My corpus shows that kank-á(ta) 'this much/many, to this degree' is a demonstrative that is used as an adjectival (quantitative) modifier of nouns, as a quantitative pronoun, and as an adverbial degree modifier of adjectives and of verbs. In the following, these functions are discussed in turn.

In its primary function, kank-á(ta) is used as an adjectival modifier of a noun. As such, it agrees obligatorily in case and gender with the head noun. The demonstrative identifies a quantity, which is either demonstrated gesturally or mentioned in the preceding discourse. The identified quantity can be a countable number or an uncountable amount.

${ }^{25}$ Hittigoon-á(ta) and hittigaam-ú/-ita have no intensifying use, unlike, e.g., English such, Dutch zulk and Odia emiti/semiti (van der Auwera \& Sahoo 2015: 147, 157, 167).

26 See also the derived adjectives gorr-áam- $u$ 'hungry' in (3), dan-aam-ita 'beautiful' in (10), sas-lokk-áam-u 'three-legged' in (40) and maq-aam-ú 'strong' in (48).

27 In the schoolbooks (K89), we also find the spelling hiwank-á(ta). 
$\begin{array}{llll}\text { (44) Án } & \text { kank-áta } & \text { az-úta } & \text { aass-áamm } \\ \text { 1S.NOM } & \text { EQ1_A_DEM-F.ACC } & \text { milk-F.ACC } & \text { give-1S.IPV }\end{array}$

(a) Exophoric use (speaker indicates amount with his/her hands): 'I give this much milk.' (b) Use as a placeholder for a quantitative expression: 'I give so-and-so much milk.' (EK2016-02-23; meaning (b) in the recording)

As all other adjectives in the language, $k a n k-a ́(t a)$ can be used in place of a noun. The missing head noun is understood from the linguistic or extra-linguistic context. In (45) it is world knowledge about transactions that enable the interlocutor to fill in the unexpressed referent of kank-iin 'with this much', namely 'with this much money'. The linguistic or extra-linguistic context determines the quantitative target of demonstration. The sentence, which originates from elicitation, ${ }^{28}$ permits at least two interpretations: (i) The speaker expects people to be surprised because he spent so little or so much money (in absolute terms), or (ii) kank-íin identifies a quantity expressed in the discourse or, less likely in this particular example, a quantity indicated by a gesture.

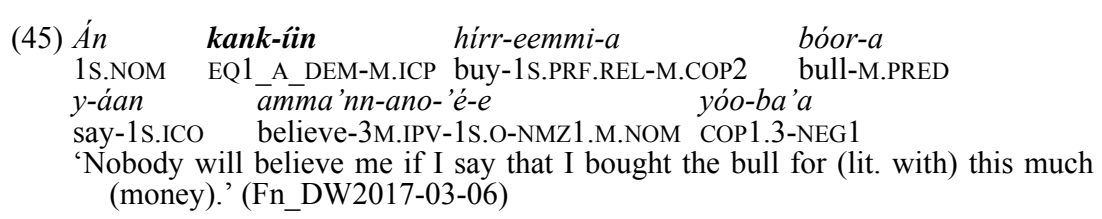

In its secondary function, $k a n k-a(t a)$ is used adverbially and occurs invariably in the masculine accusative form. In (46) it modifies a predicative adjective, in (47) a subordinate property ideophone, and in (48) an adjective used nominally as NP head. The antecedent of kank-ánka in (46) is the degree of length, the two meters, mentioned in the preceding sentence; the demonstrative is here used with endophoric (anaphoric) reference. The demonstrative identifies the degree of beauty of the pictures in (47) and the degree of size/strength of the leopard in (48). In (47) and (48), the degree is identified in the external world, i.e. kanka-sii and $k a n k$-á are here used with exophoric reference.

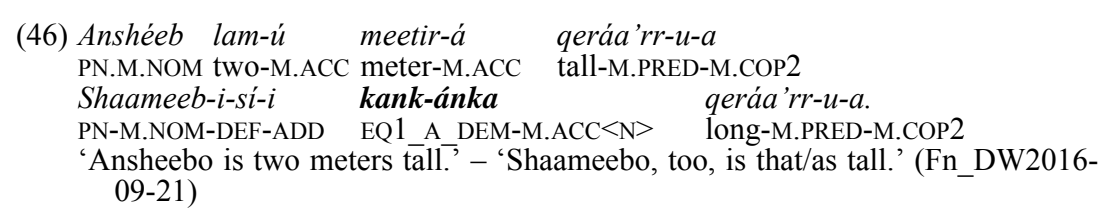

28 A native speaker was given the following task: Can you think of a possible sentence in which the form kankiin occurs? 

(47) (...) kánn od-ée misil-iichch wol-i-s A_DEM1.M.OBL fig_tree-F.GEN picture-M.ABL other-F.ACC-DEF $\begin{array}{lll}\text { kank-a-sí-i } & \text { cúlu=a'-ii } & \text { dand-itim-bá 'a } \\ \text { EQ1_A_DEM-M.ACC-DEF-ADD } & \text { be_beautiful.IDEO=do-M.DAT be_able-3F.NIPV- } \\ \text { NEG1 } & \end{array}$
'(Although I have made a real effort to draw all pictures beautifully), (pictures) others than this picture of a fig-tree do not seem as beautiful.' (Fn_DW2017- 02-08)
(48) Kank-á maq-aam-ú hakkánn-e maax-áammi-la?
EQ1_A_DEM-M.ACC strength-AAM-M.ACC where-M.OBL hide-1S.IPV-MIT
(Exophoric reference:) 'Where can I hide such a strong (i.e. big) (leopard as you are)?' (K89: 4.76)

If the demonstrative is an adverbial to a non-gradable verb (49), it identifies the intensity of a verbal action or the quantity of an affected object.

$\begin{array}{lllr}\text { (49) Kank-á } & \text { kaakkées-S } & \text { kank-á } & \text { quphphá' }[-i] ? \\ \text { EQ1_A DEM-M.ACC } & \text { cackle-2S.PCO } & \text { EQ1 A DEM-M.ACC lay eggs-2S.PCO }\end{array}$

(Proverb used with exophoric reference, most common interpretation:) 'You cackled this much for laying this few eggs!' (A\&A 2017)29

In addition to the identifying use illustrated in the examples presented so far, kank$\dot{a}(t a)$ also has an intensifying use. In examples such as (50), taken from a written text, and (51), observed in a conversation, the demonstrative does not identify a quantity - there is no previously mentioned suitable antecedent - but it serves the purpose of intensification and expresses a high (absolute) quantity. ${ }^{30}$ This can be observed for adnominal as well as adverbial equative demonstratives. It is noteworthy that the intensifying use is very common in, but not restricted to negative environments.
(50) Yam-óo
kánk-at
gén-it
yóo-si-ba'a
mouse-M.NOM EQ1_A_DEM-F.NOM harm-F.NOM COP1.3-3M.O-NEG1

(Non-deictic use in the quoted source) 'Mice are not very harmful (lit. Mice, there is not this much harm to them).' (K89: 3.32) ${ }^{31}$

\footnotetext{
${ }^{29}$ The sentence also allows for another interpretation, which is, however, not very likely in the cultural context: 'You cackled this little for laying this many eggs.'

30 The intensifying use of similative and equative demonstratives is also discussed elsewhere in the literature, see, for instance, Umbach \& Ebert (2009) on German so, van der Auwera \& Coussé (2016) on English such and Swedish sådan, Arsenijević et al. (2016) on Cantonese gam3. Note, however, that while the Kambaata equative demonstrative is often used for intensification, this use is not attested for the similative demonstratives hittigoon-á(ta) and hittigaam-ú/-ita 'such' (§6.2).

${ }^{31}$ In another context, the same sentence may allow an anaphoric reading of kánk-at: 'Mice are not as harmful (e.g. as other previously mentioned animals).'
} 
(51) Kank-á abb-is-áno-ba'a

EQ1_A_DEM-M.ACC be_great-CAUS1-3M.IPV-NEG1

(Context: Do the Alaaba people celebrate the masaala-holiday? - Answer:) 'They don't celebrate it very much (lit. this much).' (Overheard) ${ }^{32}$

The negation does not need to be overtly expressed but is often inferred. Negative inference is only triggered if $k a n k-a ́(t a)$ is used predicatively, as several examples in written sources and in my field notes show. In (52), the predicate kánk-a-anka 'it is that much' needs to be translated as '(it) is not that much', although the sentence does not contain a negative morpheme. ${ }^{33}$ The utterance kánk-a-anka is also a very common way of expressing an average degree or quantity, e.g. Danáam-u-a-ndo? 'Is it good?' - Kánk-a-anka 'So, so.'

(52) $W o ́ l-u=r r-u \quad$ isé=tannee $\quad k u l$-eennó $=r-u$ other-M.NOM=NMZ.P-M.NOM 3F.GEN=about tell-3HON.IPV.REL=NMZ.P-M.NOM kánk-a-anka

EQ1_A_DEM-M.PRED-M.COP $2<\mathrm{N}>$

(Context: Narrator gives a very brief description of a flower.) 'There is not that much else to say about it (lit. Other things that one (could) tell about her are that much).' (QL 2018)

Although the occurrences of the second equative demonstrative adjective, hibank$a ́(t a)$ 'this much/many, to this degree', are clearly outnumbered by those of kank$a ́(t a)$, we find examples both in spontaneously produced and elicited data. In (53) hibank-ánka identifies the degree of difficulty, in (54) the degree of smallness. In both cases, the first and second equative demonstrative can be used interchangeably.

(53) Kabar-é faxán-u hibank-ánka kee'máashsh-a-a-ba'a today-M.GEN exam-M.NOM EQ2 A DEM-M.ACC $<$ N $>$ difficult-M.PRED-COP2-NEG1 (Context: Yesterday's exam was difficult.) 'Today's exam isn't that difficult.' (Fn_DW2017-04-21)

$\begin{array}{llll}\text { (54) Án } & \text { m-iiha-at } & \text { hibank-áta }{ }^{34} & \text { qakk-ichch-úta } \\ \text { 1S.NOM } & \text { what-M.DAT-COP3 } & \text { EQ2_A_DEM-F.ACC } & \text { small-F.ACC }\end{array}$

ik-koommi-ihu?

become-1S.PFV.REL-NMZ1-M.NOM

(Context: Protagonist looking at herself) 'Why am I so small?' (Fn2016 based on TD2016-02-11_001)

If no parameter of comparison is expressed, which is typically the case when the equative demonstrative is used as an adnominal modifier (55) or as the head of an

32 In another context, the same sentence may allow an anaphoric reading of kank-á: 'They do not celebrate it as much (e.g. as other previously mentioned ethnic groups).'

33 Again, given an appropriate context, kánk-a-nka also allows a deictic reading: 'It is this much (e.g. as indicated by a gesture).'

${ }^{34}$ It is unclear why a feminine accusative form is used here for a demonstrative in adverbial function. 
NP (56), it identifies a quantity, either an uncountable amount (55) or a countable number (56).

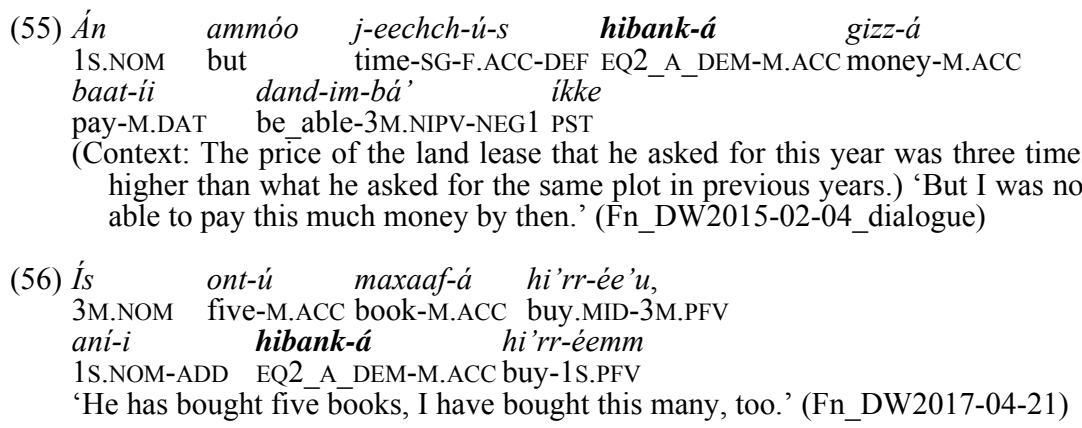

As has been observed for kank-á(ta) in (50-51) above, hibank-á(ta) also allows for an intensifying use (57).

(57) Hibank-á qee'rr-á woqq-áa hoolam-á marámm-ee-bala! EQ2 A DEM-M.ACC far-M.ACC road-M.ACC much-M.ACC walk.PASS-3M.PRF-?

'He had (already) travelled such a long distance (lit. far road) and this much (i.e. a very long distance and very much).' (QL 2018)

As far as I can judge from substitution tests and a study of the contexts in which the two equative demonstratives occur, they can be considered true synonyms.

\section{Demonstrative-interrogative relationship}

As in many languages of the world (see Diessel 2003), Kambaata demonstratives and interrogatives share morphological and semantic features. The most extensive formal conformity is observed between certain interrogatives and medial demonstratives (DEM2), which only differ with regard to the first stem vowel, $i$ for medial demonstratives and $a$ for interrogatives (Table 9). The interrogatives inflect exactly like their demonstrative counterparts; their case, gender, number paradigms are congruent and they display the same stem alternations (see Treis 2008: 285f, 297f, 325f, 382-94 on interrogatives). Furthermore, certain interrogatives and demonstratives underlie identical derivational mechanisms, see the adjectival derivational morphemes -aam and -oon that form part of the quality interrogatives and demonstratives. Time and directional forms have the same morphological structure, too. Table 9 presents all Kambaata interrogatives with the exception of ayé 'who?', má 'what?' and me'-ú/-ita 'how many, how much (of a price)?', which have no formally corresponding demonstratives. 


\begin{tabular}{|c|c|}
\hline Demonstrative adjective ('that' DEM2) & híkka $(\mathrm{M}) /$ hitta $(\mathrm{F})$ \\
\hline Selection interrogative adjective ('which?') & hákka (M)/ hátta (F) \\
\hline Demonstrative pronoun ('that one' DEM2) & hikkáan (M) / hittáan (F) \\
\hline Selection interrogative pronoun ('which one?') & hakkáan (M) / hattáan (F) \\
\hline Manner demonstrative pronoun ('like this') & hitt-ita $\sim$ hittig-úta \\
\hline Manner interrogative pronoun ('how?') & hatt-ita $\sim$ hattig-úta \\
\hline Quality demonstrative adjective ('such') & hittig-oon-á(ta) hittig-aam-ú/-ita \\
\hline Quality interrogative adjective ('which kind of?') & hattig-oon-á(ta) hattig-aam-úl-ita \\
\hline $\begin{array}{l}\text { Degree/quantity demonstrative adjective } \\
\text { ('to this degree, this much/many') }\end{array}$ & hibank-á(ta) \\
\hline $\begin{array}{l}\text { Degree/quantity interrogative } \\
\text { ('to what degree, how much?', *'how many?') }\end{array}$ & habank-á(ta $)^{35}$ \\
\hline Directional demonstrative ('to there') & $\begin{array}{l}\text { hikka=b-á } \\
{[\mathrm{P} \text { DEM2.M.ACC }=\text { PLACE-M.ACC }]}\end{array}$ \\
\hline Directional interrogative ('to where?') & $\begin{array}{l}\text { hakka=b-á } \\
\text { [which.M.ACC=PLACE-M.ACC] }\end{array}$ \\
\hline Time demonstrative ('then') & $h i k k a=d a$ [P_DEM2.M.ACC $=$ COND $]$ \\
\hline Time interrogative ('when?') & $h a ́ k k a=d a$ [which.M.ACC $=\mathrm{COND}]$ \\
\hline
\end{tabular}

Table 9. Demonstratives and selection interrogatives compared.

With respect to the equative and similative demonstratives discussed in $\$ 6$ we note that the first equative demonstrative kank-á(ta) 'this much/many, to this degree' has no formally related separate interrogative counterpart - it "shares" an interrogative with the synonymous hibank-á(ta) 'this much/many, to this degree'. The semantic categories of the interrogatives in Table 9 match those of the demonstratives almost perfectly - with one exception: The domain of degree and quantity is not carved up in the same way for demonstratives and interrogatives. The equative demonstratives kank-á(ta) and hibank-á(ta) can identify a degree, a countable and an uncountable quantity (\$6.3). In contrast, the interrogative habank-á(ta) 'to what degree, how much, how old?', which corresponds formally to the second equative demonstrative, can only inquire about a degree and an uncountable quantity (58); a countable quantity (number) is necessarily inquired about by me'-ú / me'-ita 'how many, how much (of a price)', an interrogative which belongs to the adjectival subclass of numerals (59) (Treis 2008: 94, 317).

(58) Ann-íiha-n-s

habánk-u

gizz-u

father-M.DAT-L-3M.POSS how much-M.NOM money-M.NOM

yóo-si-a-n?

COP1.3-3M.O.REL-M.COP2-Q

'How much money does his father have?' (QL 2018)

(59) Mé-it hiz-áakk-at yóo-si-a-n? (..)

how many-F.NOM sibling-PL2-F.NOM COP1.3-3M.O.REL-M.COP2-Q

'How many siblings does he have?' (QL 2018)

35 In the schoolbooks (K89), we also find the spelling hawank-á(ta). 
We have seen in $\$ 6.3$ above that the equative demonstratives have an intensifying use. The same can be observed for their interrogative counterpart habank-á(ta) 'to what degree, how much?', when combined with the interrogative morpheme -ndo and used in a non-interrogative context (60).

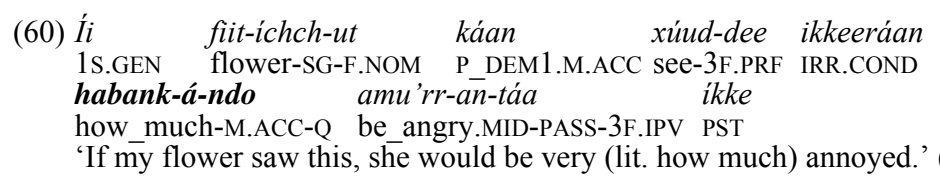

Alternatively, the interrogative phrase m-íi qax-ándo lit. '(to) the extent of what?' is used for intensification (61). Recall from $\S 4$ that $q a x$-á 'extent' is a standard marker in equative constructions.

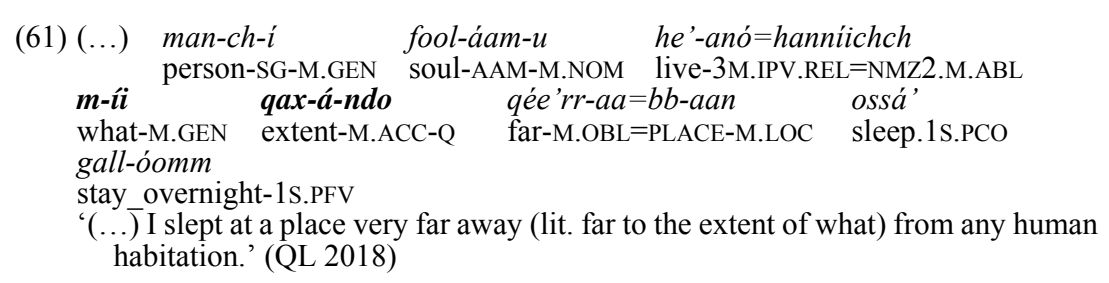

\section{CONCLUSION}

In addition to a morphologically fairly complex system of demonstrative adjectives, demonstrative pronouns and presentative demonstratives, Kambaata has six similative and equative demonstratives, whose morphology, morphosyntax and use have been examined in detail in the preceding sections. Similative and equative demonstratives have neutralised the four deictic oppositions that we find in other Kambaata demonstratives. Formally, similative and equative demonstratives resemble most closely the medial forms of other demonstratives.

\begin{tabular}{|l|l|l|l|}
\hline \multirow{2}{*}{ Similative } & $\begin{array}{l}\text { Ontological } \\
\text { type }\end{array}$ & $\begin{array}{l}\text { Typical syntactic } \\
\text { function }\end{array}$ & Form \\
\cline { 2 - 4 } & Manner & adverbial & hitt-íta / hittig-úta 'like this' \\
\cline { 2 - 4 } & Quality & adnominal & $\begin{array}{l}\text { hittig-oon-á(ta)/ } \\
\text { hittig-aam-ú/-íta 'such' }\end{array}$ \\
\hline Equative & Degree & adverbial & kank-á/hibank-á 'to this degree' \\
\cline { 2 - 4 } & Quantity & adnominal & kank-á(ta) / hibank-á(ta) 'this much' \\
\hline
\end{tabular}

The two manner and two quality demonstratives are subsumed under the label similative demonstratives. The first manner demonstrative, hitt-ita 'like this', is clearly a simplex pronoun; the second, hittig-úta 'like this', is synchronically not segmentable but can be assumed to result historically from a compositional form containing an element $* g$ 'manner'. The manner demonstratives are predominantly 
used in adverbial function and have a reduced pronominal case system. Both are interchangeable when used exophorically and endophorically; they have, however, developed distinct non-deictic uses. The synonymous quality demonstratives hittig-oon-á(ta) and hittig-aam-ú/-ita 'such' are derived in a morphologically transparent way from the second manner demonstrative. They are members of the word class adjective. As adjectives, they can be used not only as modifiers of nouns but also in place of nouns as NP heads.

In addition, Kambaata has two synonymous equative demonstratives, kank$a ́(t a)$ and hibank-á(ta) 'this many/much, to this degree', which are also adjectival in nature. As adjectival modifiers of nouns they identify a quantity; as adverbial modifiers of adjectives, property verbs and ideophones they identify a degree. As adjectival modifiers they display case/gender agreement, in adverbial function they occur invariably in the masculine accusative form. Unlike quality demonstratives, Kambaata degree/quantity demonstratives are commonly used non-deictically as intensifiers.

The formal similarity between manner and quality demonstratives in Kambaata, on the one hand, and the formal difference between manner/quality and degree demonstratives, on the other hand, gives further support for the tentative observation that syncretism between manner and quality is probably more common cross-linguistically than syncretism between either manner or quality and degree. This observation of a reviewer is briefly addressed but not confirmed in König \& Umbach (2018: 304). Spanish and Italian are given as examples of languages with this recurrent type of syncretism, which might reflect that manner/quality and degree are conceptualised differently. Arsenijević et al. (2016) have recently shown for Cantonese, Mandarin and Czech that even in languages where manner, quality and degree deixis are expressed by the same terms, manner and quality demonstratives can be shown to share certain tonal and morphological characteristics that set them apart from degree demonstratives.

The recurrent patterns of syncretism between manner, quality, degree and, I would like to add, quantity demonstratives deserve attention in future investigations of equative and similative demonstratives worldwide.

\section{ACKNOWLEDGEMENTS}

I am indebted to Deginet Wotango, Teshome Dagne, Alemu Banta, Aman Nuriye, Ermias Kenore and Tessema Handiso and all my other Kambaata consultants. Research for this paper was sponsored by the federation Typologie et universaux linguistiques : données et modèles (CNRS, FR 2559) via the project Expression des comparaisons d'égalité et de similitude (2014-2018). Thanks to two anonymous reviewers and to Marine Vuillermet for comments on an earlier version of this paper. 


\section{REFERENCES}

Anderson S.R. \& Keenan E.L. 1985, Deixis, in T. Shopen (ed), Language typology and grammatical description, vol. 2: Grammatical categories and the lexicon, Cambridge, Cambridge University Press, p. 259-308.

Arsenijević B., Kratochvíl F. \& Sio J.U.S., 2016, Equative and simulative demonstratives in Sinitic and beyond, Paper presented at the $15^{\text {th }}$ International Symposium on Chinese Languages and Linguistics (IsCLL-15).

Crass J., 2005, Das K'abeena. Deskriptive Grammatik einer hochlandostkuschitischen Sprache, Cologne, Köppe.

Crass J., 2017, Similarity and related functions in Libido, in Y. Treis \& M. Vanhove (ed), Similative and equative Constructions: A cross-linguistic perspective, Amsterdam/Philadelphia, Benjamins, p. 387-417.

Diessel H., 1999, Demonstratives: Form, function and grammaticalization, Amsterdam/Philadelphia, Benjamins.

Diessel H., 2003, The relationship between demonstratives and interrogatives, Studies in Language 27(3), p. 635-655.

Dixon R.M.W., 2003, Demonstratives: A cross-linguistic typology, Studies in Language 27(1), p. 61-112.

Dukamo Duguna, 2014, Documentation of the form and function of Sidaama demonstratives, M.A. thesis, Addis Abba University.

Guérin V., 2015, Demonstrative verbs: A typology of verbal manner deixis, Linguistic Typology 19(2), p. 141-199.

Haspelmath M. \& Buchholz O., 1998, Equative and similative constructions in the languages of Europe, in J. van der Auwera \& D.P. O Baoill (ed), Adverbial constructions in the languages of Europe, Berlin, Mouton de Gruyter, p. 277334.

König E., 2012, Le rôle des déictiques de la manière dans le cadre d'une typologie de la deixis, Bulletin de la Société de Linguistique de Paris CVII, p. 11-42.

König E., 2015, Manner deixis as source of grammatical markers in IndoEuropean languages, in C. Viti (ed), Perspectives on historical syntax, Amsterdam/Philadelphia, Benjamins, p. 33-60.

König E., 2017, The deictic identification of similarity, in Y. Treis \& M. Vanhove (ed), Similative and equative constructions: A cross-linguistic perspective, Amsterdam/Philadelphia, Benjamins, p. 143-164.

König E. \& Umbach C., 2018, Demonstratives of manner, of quality and of degree: A neglected subclass, in M. Coniglio, A. Murphy, E. Schlachter \& T. Veenstra (ed), Atypical demonstratives: Syntax, semantics and pragmatics, Berlin, De Gruyter Mouton, p. 285-328.

Schneider-Blum G., 2007, A grammar of Alaaba, a Highland East Cushitic language of Ethiopia, Cologne, Köppe.

Treis Y., 2008, A grammar of Kambaata, Part 1: Phonology, morphology, and non-verbal predication, Cologne, Köppe.

Treis Y., 2017, Similative morphemes as purpose clause markers in Ethiopia and beyond, in Y. Treis \& M. Vanhove (ed), Similative and equative constructions: A cross-linguistic perspective, Amsterdam/Philadelphia, Benjamins, p. 91142.

Treis Y., 2018, Comparison in Kambaata: Superiority, equality and similarity, Linguistic Discovery 16(1), p. 65-100 (Special issue On the expression of comparison: Contributions to the typology of comparative constructions from lesser-known languages, edited by Y. Treis \& K.I. Wojtylak). 
Treis Y., forthcoming, Presentative demonstratives in Kambaata from a Cushitic perspective, in Du terrain à la théorie. Les 40 ans du LACITO, Villejuif, LACITO.

Umbach C. \& Ebert C., 2009, German demonstrative so - intensifying and hedging effects, Sprache und Datenverarbeitung 1-2, p. 153-168.

Umbach C. \& Gust H., 2014, Similarity demonstratives, Lingua 149, p. 74-93.

Van der Auwera J. \& Sahoo K., 2015, On comparative concepts and descriptive categories, such as they are, Acta Linguistica Hafniensia 47(2), p. 136-173.

Van der Auwera J. \& Coussé E., 2016, Such and sădan - the same but different, Nordic Journal of English Studies 15(3), p. 15-32.

\section{SOURCES}

Field notes are marked as "Fn" followed by a speaker abbreviation, a date and (optionally) a subject (e.g. Fn TH2003-0926 masaala). Recorded data is marked by a speaker abbreviation, a date and a track number (e.g. TD2016-02-11_001). Data from the following locally published sources has been checked with a native speaker. I have added morpheme glosses, stress marks and translations of the data.

A\&A = Alamu Banta \& Alamaayyo G/Xiyoon, 2017, Hambarrichcho yaanata . Kambaatissa-Amaarsa hayyo'ooma yannaakkata, Addis Ababa, AAU.

$\mathrm{B} \& \mathrm{Y}=$ Brook Kebede \& Yonathan Zeamanuel, 2013, Mannu ichchaan xalliin heanoba'a, translated by Tarekegn Sadore, Getahun Jorge, Berhanu Erango, [n.p.], Catholic, Evangelical, Orthodox Churches \& Mekane Yesus.

$\mathrm{GH}=$ Geetaahun Heelleebo Baachchoore, 2002, Kambaatissa afgale maxaafa, Tungu, Kambaatina Xambaaro Zoonaan Dooyyoganni Woradaan MaareAmmachcho Waato.

John = Kambaaata and Hadiyya Translation Project Hosaina, 2005, Qarichcho Yesuus Kiristoositannee Yohannis xaaffo mishiraachchi maxaafa [Latin version of the Gospel of John in the Kambaata language], Addis Ababa, Bible Society.

K89 = Kambaatissata. Rosaanchi maxaafa [Kambaata language. School book], 1989 E.C., Grade 1-8, Southern Nations, Nationalities, and Peoples Regional State, Education Bureau.

$\mathrm{NJ}=$ Nibaabi Jaalae 1-5, 2004, Addis Ababa, Spotlight Publishers PLC.

$\mathrm{QL}=$ Saint-Exupéry, Antoine de 2018. Qakkichchu Laaha [The Little Prince]. Transl. by Deginet Wotango Doyiso \& Y. Treis, Neckarsteinach, Tintenfaß. 